University of Nebraska - Lincoln

DigitalCommons@University of Nebraska - Lincoln

Faculty Publications - Chemistry Department Published Research - Department of Chemistry

2001

\title{
Multiple Separations Facilitate Identification of Protein Variants by Mass Spectrometry
}

Zhongli Zhang

University of Nebraska - Lincoln

David L. Smith

University of Nebraska - Lincoln, dsmith7@unl.edu

Jean B. Smith

University of Nebraska - Lincoln, jsmith8@unl.edu

Follow this and additional works at: https://digitalcommons.unl.edu/chemfacpub

Part of the Chemistry Commons

Zhang, Zhongli; Smith, David L.; and Smith, Jean B., "Multiple Separations Facilitate Identification of Protein Variants by Mass Spectrometry" (2001). Faculty Publications -- Chemistry Department. 21. https://digitalcommons.unl.edu/chemfacpub/21

This Article is brought to you for free and open access by the Published Research - Department of Chemistry at DigitalCommons@University of Nebraska - Lincoln. It has been accepted for inclusion in Faculty Publications -Chemistry Department by an authorized administrator of DigitalCommons@University of Nebraska - Lincoln. 


\title{
Multiple separations facilitate identification of protein variants by mass spectrometry
}

\author{
Zhongli Zhang, David L. Smith and Jean B. Smith* \\ Department of Chemistry, University of Nebraska, Lincoln, NE 68588-0304, USA \\ E-mail: jsmith8@unl.edu
}

\begin{abstract}
Identification of variant proteins from complex biological samples promises to contribute much to our understanding of the etiology of pathological states. Characterization of variants, due either to genetic mutations in protein sequences or to post-translational modifications, is considerably more difficult than the simple protein identifications typical of most current proteomic investigations. Identification of a few peptides by database retrieval is not adequate when the goal is to have a complete understanding of the modifications of the protein. Although one advantage of mass spectrometry is its ability to obtain specific responses to several components, the complexity of biological samples is often overwhelming, resulting in spectra lacking useful information. For complex mixtures, isolation procedures before mass spectrometric analysis may need to include a variety of chromatographic and electrophoretic separation techniques. In this report, we illustrate how several preparative steps were essential for obtaining information about modified human lens $\beta$-crystallins. The preparative techniques prior to mass spectrometry included size-exclusion chromatography, reversed-phase chromatography, two-dimensional gel electrophoresis, in situ digestion of the proteins and peptide trapping and washing before a final reversed-phase high-performance liquid chromatographic separation on-line to the mass spectrometer. This approach for isolation and analysis, when customized for other proteins, should find application in many studies where protein variants of complex mixtures are to be identified.
\end{abstract}

Keywords: chromatography, gel electrophoresis, HPLC/electrospray ionization mass spectrometry, lens $\beta$-crystallins, tandem mass spectrometry

\section{Introduction}

The primary goal of most proteomic endeavors has been to identify proteins separated by two-dimensional gels, with particular attention to those found in pathological conditions. In this mission, a common approach is to enzymatically digest the protein in situ, elute the peptides and identify several peptides by matching their molecular masses, determined by mass spectrometry, with expected molecular masses of peptides from proteins with known sequences. ${ }^{1}$ For positive identification, the fragmentation patterns from analysis by tandem mass spectrometry (MS/MS) can be used to confirm the sequence. Success in identifying a protein often requires identification of only a few peptides. ${ }^{2}$

However, simple identification of the protein is not sufficient for an understanding of the role of proteins in disease states. For proteomics to reach its potential in pathology,

This paper is being publi shed jointly in European Journal of Mass Spectrometry and in Proteomics (ISSN 1615-9853). protein variants, both genetic variants in the amino acid sequences and post-translational modifications, will need to be identified. It will not be sufficient to identify a few peptides eluted from a gel by matching masses with protein databases. Peptides from all portions of the protein sequence must be retrieved from the gel and their masses and sequences determined. In addition, in making these identifications, the presence of peptides from more than one protein in the same digest is likely to cause confusion. Although the ability to analyze mixtures is one of the major advantages of mass spectrometry, ${ }^{3,4}$ complete analysis of proteins present in complex mixtures often requires one or more steps of separation prior to analysis. ${ }^{5-7}$ Both chromatography and electrophoresis have been used extensively to purify proteins prior to analysis by mass spectrometry. ${ }^{8,9}$ This contribution demonstrates the advantage of combining several isolation techniques prior to mass spectrometry to maximize information about proteins in mixtures

The proteins of the human lens, called crystallins, provide an example of the complexity of proteins in biological samples. Although the human lens has only eleven gene 
products, the crystallins, which do not undergo turnover, become extensively modified with aging, leading to a complex mixture of proteins in older lenses. ${ }^{10}$ Identification of these modified proteins is of particular interest because they are likely the precursors of cataract, the principal cause of blindness worldwide. Because of their high sequence homology and extensive modification, the crystallins are difficult to separate. In our studies, we have found that neither chromatography nor two-dimensional gel electrophoresis alone provides adequate separation for mass spectrometric analysis. The similar hydrophobicity of some crystallins permits only partial separation by reversed-phase high-performance liquid chromatography (HPLC) ${ }^{11}$ and, likewise, the similar pI values and charge changes of some of the modifications prevent adequate separation by ion exchange. ${ }^{12}$ Even with dual separation by molecular mass and $\mathrm{pI}$ in two-dimensional gel electrophoresis, some proteins with very different sequences migrate to the same position. ${ }^{13} \mathrm{We}$ have found that a combination of several types of chromatography and electrophoresis, taking advantage of the unique separating powers of each, permits sufficient separation for mass spectrometric analysis of the entire sequence of the protein. The procedure includes several chromatographic steps before two-dimensional gel separation, followed by elution of proteins either intact or as peptides after enzymatic digestion, with subsequent trapping and washing to remove components that would interfere with mass spectrometric analysis. Determination of the molecular masses of the proteins and peptides by on-line capillary HPLC/MS with further analysis by MS/MS then permits complete identification of all the protein modifications. With appropriate variations, procedures similar to this method, which was developed specifically for lens $\beta$ crystallins, may find application for other proteins.

\section{Materials and methods}

\section{Chemicals}

Bromophenol blue, dithiothreitol (DTT), CHAPS, pH 3-10 non-linear (NL) Immobiline DryStrips, pH 3-10 NL immobilized $\mathrm{pH}$ gradient (IPG) buffer and DryStrip cover fluid were purchased from Amersham Pharmacia Biotech (Piscataway, NJ, USA). Urea was from Gallard-Schlesinger Industries (Carle Place, NY, USA). HPLC-grade acetonitrile was from EM Science (Gibbstown, NJ, USA). Sequencinggrade modified trypsin was obtained from Promega (Madison, WI, USA). All other chemicals were from Sigma Chemical Co. (St Louis, MO, USA).

\section{Preparation of water-soluble human lens crystallins}

Normal transparent lenses, ages 2, 55, 56 and 59 were obtained from the Lions Eye Bank, Omaha, NE, USA. The donor history for each clear lens did not indicate any diseases associated with cataracts. Each lens was individually homogenized using a stirring bar for three hours in $2.5 \mathrm{~mL}$ of
$50 \mathrm{mM}$ MES buffer containing $0.9 \% \mathrm{NaCl}, 1 \mathrm{mM}$ EDTA and $1 \mathrm{mM}$ DTT $\left(\mathrm{pH} 6.0\right.$ ) at $4^{\circ} \mathrm{C}$. After centrifugation at $15,000 \mathrm{~g}$ and $4^{\circ} \mathrm{C}$ for one hour, the water-soluble and waterinsoluble crystallins were separated.

\section{Size-exclusion chromatography of water-soluble human lens crystallins}

The water-soluble crystallins were separated into $\alpha-, \beta-$ and $\gamma$-crystallins by size-exclusion chromatography using a Superose 6 HR column (Amersham Pharmacia Biotech) and a solvent delivery system (Dynamax, Rainin, Woburn, MA, USA). The separation was performed isocratically with the same buffer that was used for homogenization at a flow rate of $0.4 \mathrm{~mL} \mathrm{~min}{ }^{-1}$. Protein elution was monitored at $280 \mathrm{~nm}$. All the $\beta$-crystallins were collected in one fraction and used in the next step of isolation.

\section{Reversed-phase HPLC separation of water-soluble $\beta$-crystallins}

The $\beta$-crystallins isolated by size-exclusion chromatography were fractionated by reversed-phase HPLC. The concentration of $\beta$-crystallins was estimated by a bicinchoninic acid assay (Pierce, Rockford, IL, USA). Before the reversedphase HPLC separation, the $\beta$-crystallins were denatured in $6 \mathrm{M}$ guanidine hydrochloride and $100 \mathrm{mM}$ DTT at room temperature overnight, acidified to $\mathrm{pH} 4.0$ by gradual addition of dilute trifluoroacetic acid (TFA) and concentrated by ultrafiltration (Centriprep 10) with a $10 \mathrm{kDa}$ cut-off (Millipore, Bedford, MA, USA). The resulting solution was centrifuged at $14,000 \mathrm{~g}$ for $10 \mathrm{~min}$ to remove water-insoluble particles. About $200 \mu \mathrm{g}$ of $\beta$-crystallins were fractionated by reversed-phase chromatography $(4.6 \times 150 \mathrm{~mm} \mathrm{C4}$ column, $300 \AA, 5 \mu$, Vydac, Hesperia, CA, USA). The proteins were eluted using $0.1 \%$ TFA in $\mathrm{H}_{2} \mathrm{O}$ (solvent $\mathrm{A}$ ) and $0.1 \% \mathrm{TFA}$ in $95 \%$ acetonitrile (solvent $\mathrm{B}$ ) and a gradient starting with $25 \%$ solvent B for $5 \mathrm{~min}$, increasing from 25 to $60 \%$ in $35 \mathrm{~min}$ and from 60 to $98 \%$ in $3 \mathrm{~min}$. The $\beta B 1$ and $\beta \mathrm{A} 4$ fractions from each run were pooled and stored at $-80^{\circ} \mathrm{C}$.

Anion-exchange chromatographic separation of the proteins in the $\beta B 1$ and $\beta A 4$ fractions obtained from reversed-phase HPLC

The $\beta \mathrm{B} 1$ and $\beta \mathrm{A} 4$ fractions collected from reversedphase HPLC were evaporated to a dry powder and re-suspended in a weak mobile phase containing $20 \mathrm{mM}$ piperazine, $6 \mathrm{M}$ urea and $0.1 \%$ DTT $(\mathrm{pH} 9.5)$ and incubated at room temperature for two to three hours. The anionexchange separation used a Mono $\mathrm{Q}$ anion-exchange column (Amersham Pharmacia Biotech). The strong mobile phase was the same buffer, but containing $0.5 \mathrm{M} \mathrm{NaCl}$. The gradient was $0-20 \%$ in $5 \mathrm{~min}$, and $20-50 \%$ in $40 \mathrm{~min}$.

\section{Identification of $\beta$-crystallins in fractions isolated by anion- exchange and/or reversed-phase HPLC}

The identities of the $\beta$-crystallins in the reversed-phase HPLC fractions and those in the anion-exchange fractions 
were determined using a single quadrupole electrospray ionization (ESI) mass spectrometer (Micromass Platform II, Manchester, UK). After desalting and urea removal, the proteins in the anion-exchange fractions were further fractionated by on-line LC/MS using a microbore column $(1.0 \times 50 \mathrm{~mm} \mathrm{C4}, 300 \AA, 5 \mu$, MicroTech, Sunnyvale, CA, USA) with a gradient of $25-55 \%$ of acetonitrile with $0.1 \%$

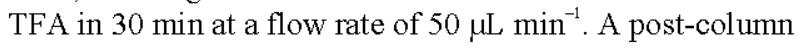
splitter (Upchurch Scientific, Oak Harbor, WA, USA) divided the flow into two portions with $10 \%$ of the flow entering the mass spectrometer and $90 \%$ collected and saved for other experiments.

\section{Two-dimensional gel electrophoresis of proteins in $\beta B 1$ and $\beta A 4$ fractions obtained from reversed-phase HPLC}

The $\beta \mathrm{B} 1$ and $\beta \mathrm{A} 4$ fractions collected from reversedphase HPLC ( $200 \mu \mathrm{g}$ per sample) were first lyophilized using a speed vacuum concentrator (Savant SC 110, Farmingdale, NY, USA) and then re-dissolved in a buffer containing $8 \mathrm{M}$ urea, $2 \%$ CHAPS, $2 \% \mathrm{pH} 3-10 \mathrm{NL}$ (nonlinear) buffer and $20 \mathrm{mM}$ DTT. To eliminate precipitation of the sample and increase the loading capacity, the sample was loaded by rehydration, in which the sample solution was absorbed by the dry IPG gel strips. The strips $(13 \mathrm{~cm})$ containing protein samples were placed on the cooling plate of a Multiphor II system (Amersham Pharmacia Biotech) and covered with mineral oil to prevent oxidation. The firstdimensional isoelectric focusing (IEF) gel electrophoresis was performed at $150 \mathrm{~V}, 300 \mathrm{~V}$ and $600 \mathrm{~V}$ for one hour in each step followed by $3500 \mathrm{~V}$ overnight (total Vh 53,550 ). The temperature was kept constant at $30^{\circ} \mathrm{C}$ using a Lauda Ecoline water circulation system (Brinkmann, Germany).

After the IEF was finished, each IPG strip was equilibrated with a buffer containing $6 \mathrm{M}$ urea and $30 \%(\mathrm{w} / \mathrm{v})$ glycerol, $2 \%(\mathrm{w} / \mathrm{v}$ ) sodium dodecyl sulfate (SDS) and 1\% $(\mathrm{w} / \mathrm{v})$ DTT for $15 \mathrm{~min}$. In the second equilibration, the strips were incubated in a buffer containing $4 \%(\mathrm{w} / \mathrm{v})$ iodoacetamide for another $15 \mathrm{~min}$. The strips were then placed on the top of pre-cast $15 \% \mathrm{~T}$ and $2.6 \% \mathrm{C}$ SDSpolyacrylamide gel electrophoresis (PAGE) gel, and fixed with $0.5 \%$ agarose. The second SDS-PAGE gel electrophoresis was performed at $100 \mathrm{~V}$ overnight using a Hoffer SE 400 vertical SDS-PAGE gel electrophoresis apparatus system (Amersham Pharmacia Biotech) with the temperature maintained at $4^{\circ} \mathrm{C}$. After the electrophoresis was completed, proteins on the SDS-PAGE gel were visualized by Coomassie blue staining. Coomassie blue staining is very reproducible but has a limit of detection of about $0.1-0.5 \mu \mathrm{g}$. The intensities of the spots usually show a linear relationship to quantity of sample (up to $20 \mu \mathrm{g} \mathrm{cm}^{-1}$ ). ${ }^{14}$ For visualization of proteins that were less abundant, negative zinc acetate staining was used because it has a limit of detection of about $5 \mathrm{ng}$. Another advantage of negative zinc acetate staining is the short staining time ( 40 to $45 \mathrm{~min}$ ), which minimizes the chance for artifactual protein modifications. ${ }^{15}$

\section{Identification of proteins in the spots of interest using electro-elution and on-line LC-ESI mass spectrometry}

Before mass spectrometric analysis, the SDS was removed from the samples, and the proteins were desalted and concentrated by passing the sample through both an SDS trap and a protein trap cartridge (Michrom BioResources, Auburn, CA, USA) connected to a 10-port Valco injection valve (Alltech, Deerfield, IL, USA). After elution from the gel in a basic buffer $(0.1 \%$ SDS, $25 \mathrm{mM}$ Tris, $0.2 \mathrm{M}$ glycine, $\mathrm{pH} 8.6$ ), the sample was acidified to $\mathrm{pH} 5.0-6.0$ by addition of dilute TFA and loaded into the SDS removal cartridge with the injector in the load position. The proteins were eluted from the SDS trap and delivered to the protein trap, where the proteins bind to the solid phase, by using $500 \mu \mathrm{L}$ of a solution of $2 \%$ acetonitrile containing $0.05 \%$ TFA. The valve was then turned to put the protein trap in line with the capillary column $(0.3 \times 50 \mathrm{~mm} \mathrm{C4}$, $300 \AA, 5 \mu$, LC-Packings, San Francisco, CA, USA) and the proteins eluted from the trap onto the column. Meanwhile, the SDS trap, which was now isolated from the protein trap, was regenerated by backflushing with $90 \%$ acetonitrile containing $0.1 \% \mathrm{HCl}$. A solvent delivery system (Shimadzu LC/10 AD VP, Shimadzu Scientific Instrument, Columbia, MD, USA) and control (Acurate Microflow Processor, IC100-VAR, LC-Packings) maintained a flow of $5 \mu \mathrm{L} \mathrm{min}{ }^{-1}$ for LC-MS. A binary system of $0.05 \%$ TFA in $\mathrm{H}_{2} \mathrm{O}$ (solvent A) and $0.05 \% \mathrm{TFA}$ in $95 \%$ acetonitrile (solvent $\mathrm{B}$ ) and a gradient of $25 \%$ solvent B for $5 \mathrm{~min}, 25-50 \%$ in $40 \mathrm{~min}$ and $50-98 \%$ in 5 min was used. Protein elution was monitored by a capillary Z-shaped U-Z View flow cell ( $8 \mathrm{~mm}$-path length, $35 \mathrm{~nL}$ volume, LC-Packings). The eluted proteins were identified by their molecular masses determined by a single quadrupole ESI mass spectrometer (Micromass Platform II).

\section{In-situ tryptic digestion of the spots containing the $\beta$ - crystallins of interest}

The spots containing $\beta$-crystallins were excized from the negative zinc acetate stained gel and the proteins in the spots were digested with trypsin in situ according to the procedure of Courchesna and Patterson ${ }^{16}$ with minor modifications. The excized gel spots were incubated in $50 \mathrm{mM}$ citric acid at room temperature for $20 \mathrm{~min}$ to mobilize the protein in the gel matrix, followed by two more incubations, each for $30 \mathrm{~min}$ in $20 \mathrm{mM} \mathrm{NH}_{4} \mathrm{HCO}_{3}+50 \%$ acetonitrile. The gel slices were then lyophilized to dryness. To perform the ingel tryptic digestion, the gel slices were placed in a mixture of $1 \mu \mathrm{L}$ of $0.1 \mu \mathrm{g} \mu \mathrm{L}^{-1}$ sequence-grade modified trypsin (Promega) and $15 \mu \mathrm{L}$ of $20 \mathrm{mM} \mathrm{NH}_{4} \mathrm{HCO}_{3}+1 \mathrm{mM} \mathrm{CaCl}_{2}$. This step was repeated until the gel slices would absorb no more solution. Additional buffer, equal to three times the volume of trypsin solution absorbed, was added and the gel slices were incubated at $37^{\circ} \mathrm{C}$ overnight. The next day, the supernatant was removed and saved. The digested peptides were extracted from the gel matrix by rotation at $37^{\circ} \mathrm{C}$ for 
$30 \mathrm{~min}$ in $200 \mu \mathrm{L}$ of $1 \%$ TFA in $60 \%$ acetonitrile and by additional rotation in $200 \mu \mathrm{L}$ of $0.1 \%$ TFA in $60 \%$ acetonitrile under the same conditions as described above. All three supernatants were combined and concentrated to $50 \mu \mathrm{L}$ by lyophilization.

\section{Characterization of modifications of $\beta$-crystallin peptides by on-line LCIMS and collision-induced dissociation (CID) tandem mass spectrometry (MS/MS)}

The peptides extracted after in situ digestion were analyzed by on-line HPLC-ESI-MS using a capillary column $\left(\mathrm{C}_{18}\right.$ Pepmap, $0.3 \times 250 \mathrm{~mm}$, LC-Packings $)$ and an ion trap ESI mass spectrometer (LCQ, Finnigan, San Jose, CA, USA). On-line desalting used a peptide-trap cartridge (Michrom BioResources) and a controlled solvent delivery system described previously. For peptide elution, a binary system of $0.01 \%$ TFA in $\mathrm{H}_{2} \mathrm{O}$ (solvent A) and $0.01 \%$ TFA in $95 \%$ acetonitrile (solvent $\mathrm{B}$ ) was used. The gradient was $2 \%$ solvent B for $5 \mathrm{~min}, 2-50 \%$ in $70 \mathrm{~min}$ and $50-98 \%$ in $3 \mathrm{~min}$. The eluted peptides were monitored at $214 \mathrm{~nm}$.

Mass spectrometric analysis of the in situ trypsin peptides used the dynamic-exclusion double-play option. The data-dependent scans, including a full scan and subsequent CID and MS/MS scan were repeated three times within 30 seconds. The exclusion duration was $2 \mathrm{~min}$ and the exclusion mass width was 1.0 mass unit. Regular double play, including full scan (profile mode) followed by CID MS/MS of selected parent ions was used for characterization of modifications of $\beta$-crystallins. The collision energy was $40 \%$, as defined by the LCQ software, and the isolation window was 2.5 mass units.

\section{Results and discussion}

To illustrate the problems that may be encountered in determining post-translational modifications of biological samples, we have chosen human lens crystallins, in particular the $\beta$-crystallins. Unmodified human lens crystallins have molecular masses of approximately $20-30 \mathrm{kDa}$. They were originally named according to the size of aggregates they form in solution and their elution pattern when separated by size-exclusion chromatography (Figure 1). The first peak, called $\alpha$-crystallins, is composed of aggregates of about $800 \mathrm{kDa}$ (40 monomers per aggregate), the second, third and fourth peaks contain differing ratios of the same six proteins ( $\beta$-crystallins) and are aggregates of $80-160 \mathrm{kDa}$, whereas the fifth peak is the monomeric $\gamma$-crystallins. The last peak contains low molecular weight (LMW) truncated proteins of less than $20 \mathrm{kDa}$. This simple chromatographic procedure is usually the initial step in simplifying crystallin mixtures for analysis. The primary difference between sizeexclusion chromatograms (Figure 1) for crystallins from a 2year-old and a 55-year-old lens is that some of the $\alpha$ crystallins elute as higher molecular aggregates (HMW) in the older lens. ${ }^{17}$

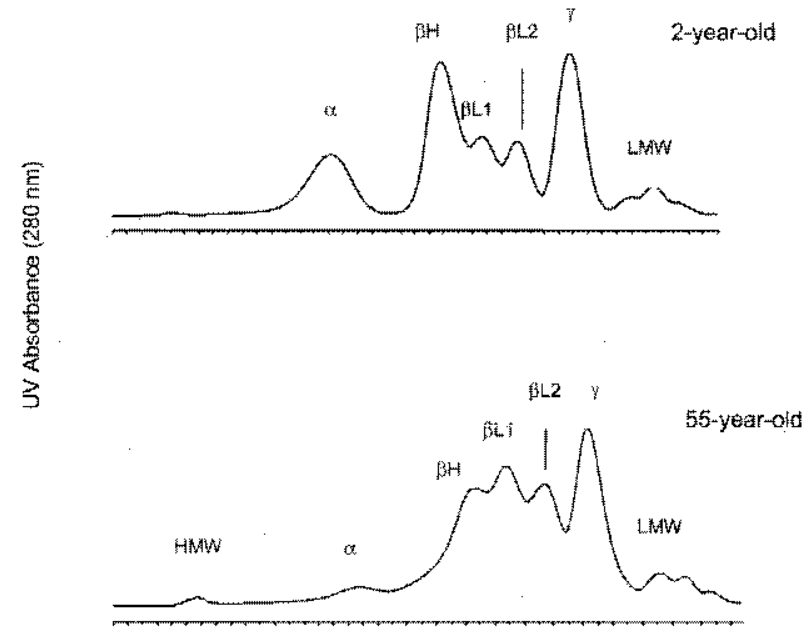

Figure 1. Chromatograms showing the size-exclusion separation of water-soluble lens crystallins from a 2-year-old lens (top) and a 55-year-old lens (bottom). The $\beta$-crystallin fractions were collected, combined and used for further analyses.

The human lens $\beta$-crystallins, which include three acidic subunits, $\beta \mathrm{A} 1, \beta \mathrm{A} 3$ and $\beta \mathrm{A} 4$, and three basic subunits, $\beta B 1, \beta B 2$ and $\beta B 3$, offer a good illustration of the advantages of multiple separation techniques in analyzing post-translational modifications. Because of the high homology of the $\beta$-crystallins and their many age-related modifications, ${ }^{13} \beta$-crystallins from adult lenses are mixtures so complex that no one electrophoretic or chromatographic procedure yields samples sufficiently simple for mass spectrometric analysis. In a previous publication using twodimensional electrophoresis, co-migration of some crystallins to the same position was evident..$^{13}$ Although in situ tryptic digestion of the proteins and analysis of the peptides by mass spectrometry identified several modified $\beta$ crystallins, the isolation was not adequate for determining the nature and location of all the modifications. ${ }^{13}$ Similarly, the peaks obtained after reversed-phase HPLC fractionation of the $\beta$-crystallins from adult lenses are complex mixtures. ${ }^{11}$ The reversed-phase HPLC chromatograms of the $\beta$-crystallins from a 2-year-old and a 55-year-old lens (Figure 2) show the $\beta A 1 / A 3$ peak becoming smaller and broader and the peaks attributed to $\beta B 1$ and $\beta A 4$ merging as the lens ages. Also, a large, broad late-eluting peak appears. The complexity of the mixture of proteins in the $\beta \mathrm{B} 1$ and $\beta \mathrm{A} 4$ HPLC peak permitted only partial identification of the modifications by mass spectrometry. ${ }^{11}$ Because of the difficulties in analyzing this peak, we have chosen the merged $\beta B 1$ and $\beta A 4$ peak to illustrate, in this report, the advantages of using multiple chromatographic and electrophoretic steps before mass spectrometric analysis.

Before deciding on the use of multiple isolation steps, a variety of alterations in the conditions for the reversed-phase HPLC were explored in attempts to improve the resolution of the $\beta$-crystallins. These alterations included use of shal- 


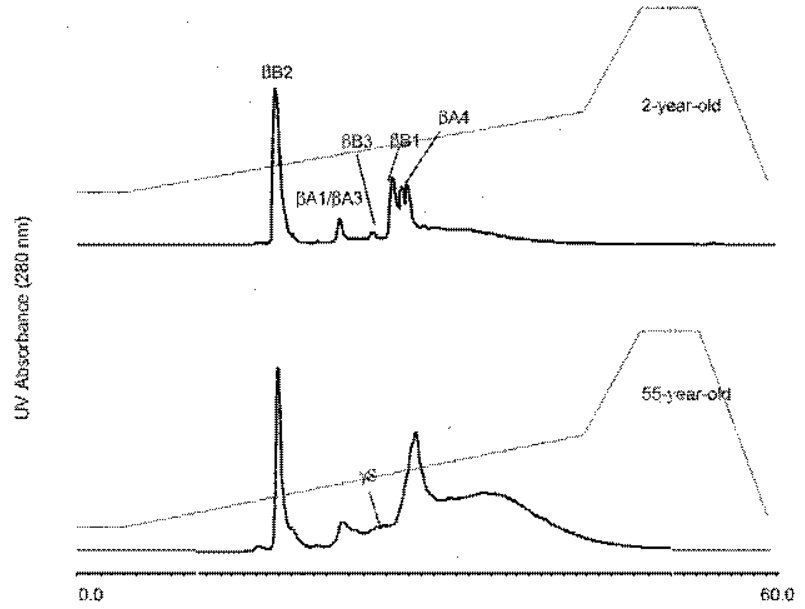

Figure 2. Chromatograms showing the reversed-phase HPLC separation of total water-soluble $\beta$-crystallins from a 2-yearold lens (top) and a 55-year-old lens (bottom). Mass spectra of the two closely spaced peaks in the chromatogram for the 2year-old lens indicated $\beta A 4$ in both. Note the peaks due to $\beta B 1$ and $\beta A 4$ in the older lens are merged. The gradient is indicated by the dotted line.

low gradients as low as $0.2 \%$ per minute, changing the organic modifier to a mixture of $50: 50$ acetonitrile + isopropanol, changing the ion-pairing reagent to heptafluorobutyric acid or formic acid and using a column jacket with a temperature of $50^{\circ} \mathrm{C}$. The effectiveness of pre-treating the proteins with $6 \mathrm{M}$ guanidine hydrochloride and $100 \mathrm{mM}$ DTT for several hours was also evaluated. None of these variations resulted in significant improvement in the HPLC resolution of the $\beta$-crystallins.

For many applications, ion exchange is effective for separating complex mixtures. Some success in separating bovine $\beta$-crystallins by anion exchange has been reported. ${ }^{18}$ However, for the human $\beta$-crystallins in the $\beta \mathrm{B} 1$ and $\beta \mathrm{A} 4$ peaks, ion exchange did not prove useful. The anionexchange chromatogram (Figure 3 ) shows four principal peaks followed by a poorly-resolved broad fraction apparently containing several components. The crystallins in each fraction were further separated by reversed-phase HPLC and analyzed by mass spectrometry. The reversed-phase HPLC chromatogram of the first peak from the anion exchange is shown in the inset of Figure 3. This HPLC chromatogram indicates the presence of as many different proteins as before the anion exchange (Figure 2). The protein in fraction $A$ was $\beta \mathrm{B} 2$, fraction $\mathrm{B}$ contained $\beta \mathrm{A} 3$ (residues $23-215$ ) and $\beta \mathrm{B} 2$ and both fractions $C$ and $D$ contained mixtures of $\beta B 2$, intact $\beta B 1, \beta B 1(16-215), \beta B 1(40-215)$ and $\beta B 1(41-215)$. These results confirmed the previously reported N-terminal cleavage of $\beta \mathrm{A} 3^{19}$ and $\beta \mathrm{B} 1 .^{20}$ The mass spectrometric analysis showed that peak 4 of the anion-exchange also contained intact $\beta \mathrm{B} 2$, but the proteins in other anion exchange fractions could not be identified due to the complexity of the mass spectra. It appears that the various $\beta$-crystallins have been extensively modified so that they co-elute on ion-exchange chromatography, preventing successful separation.

Data from two-dimensional electrophoresis of the HPLC peak containing $\beta B 1$ and $\beta A 4$ (Figure 4) demonstrated why the above techniques were not successful in producing samples that could be analyzed by mass spectrometry. The 2-year-old lens has only seven major proteins in this HPLC peak whereas the 55-year-old lens has over twenty proteins with various $\mathrm{pI}$ values and molecular masses. To obtain a more detailed analysis of the peak attributed to $\beta B 1$ and $\beta A 4$, each spot of the two-dimensional gel was digested with trypsin in situ and the peptides were eluted and analyzed by mass spectrometry. From this analysis, it was evident that this peak contained not only $\beta B 1$ and $\beta A 4$, but also some $\beta B 2$ and $\beta$ A3.

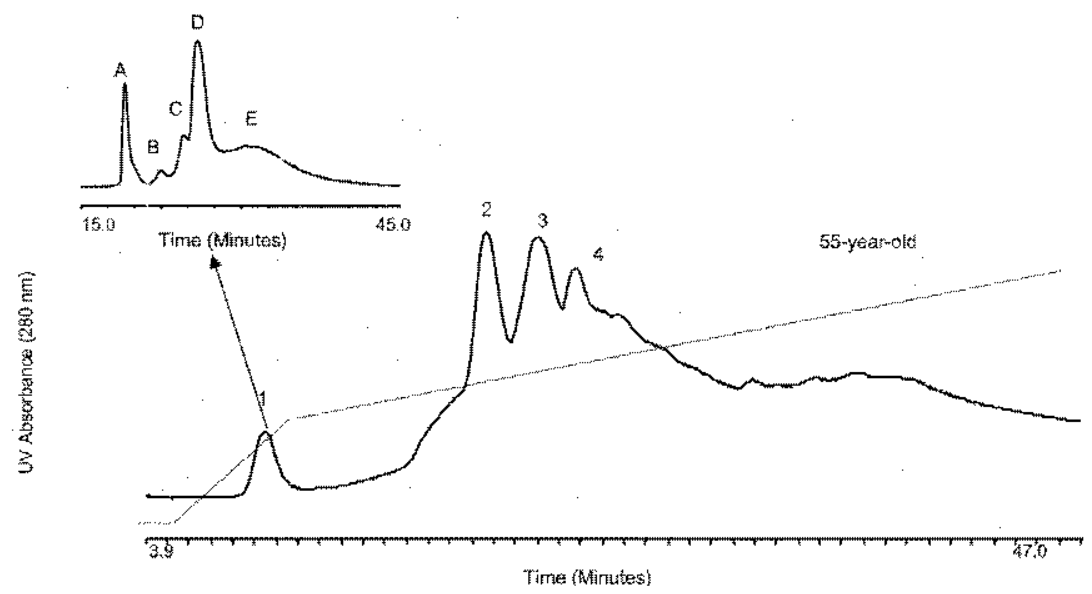

Figure 3. Chromatogram of an ion-exchange fractionation of the proteins in the $\beta B 1$ and $\beta A 4$ peak (see Figure 2 ) from a 55-year-old lens. The salt gradient is indicated by the dotted line. Reversed-phase HPLC of peak 1, shown as an inset, demonstrates that this ion-exchange fraction contains a variety of crystallins, as was observed for all the fractions. 


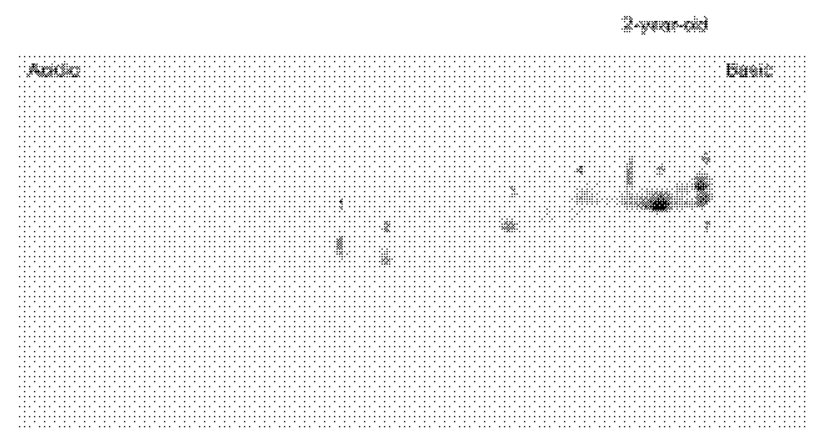

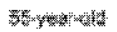

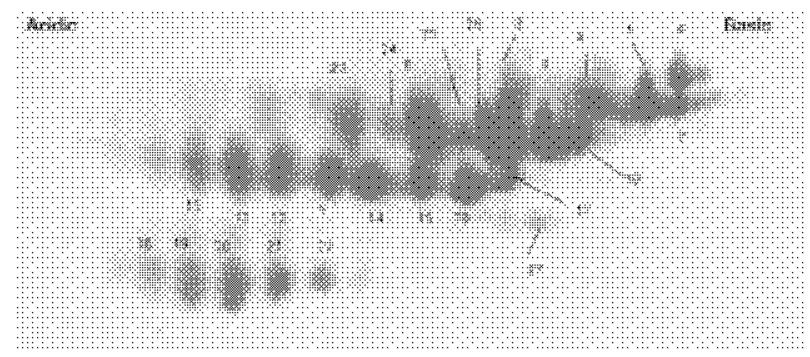

Figure 4. Coomassie blue-stained IPG two-dimensional gel of the proteins that eluted in the HPLC peak attributed to $\beta$ B1 and $\beta A 4$ (see Figure 2) from a 2-year-old lens (top) and a 55-yearold lens (bottom).

Mass spectra of intact proteins eluted from gels give useful information about the number and nature of the posttranslational modifications, but are more difficult to obtain than mass spectra of peptides after digestion of the protein. The poor mass spectra of the proteins may be due to low efficiency in eluting the proteins and/or difficulties in removing other components that interfere with the mass spectral response of the proteins. For the $\beta$-crystallins from older lenses, we were able to obtain useful spectra only for intact $\beta B 2$ eluted from several spots. Even when peptide analysis indicated that the spot contained several proteins, $\beta \mathrm{B} 2$ was often the only recognizable mass. This may be because the mass spectral response of $\beta B 2$ is better than that of other $\beta$ crystallins or because $\beta B 2$ is present with very little modification whereas the other $\beta$-crystallins are present in many forms, including a variety of truncations.

To illustrate the approach used to determine the posttranslational modifications of $\beta$-crystallins, we have chosen spot 13 of Figure 4 . This position corresponds to spot 14 in a previous publication in which the total proteins from two lenses, a 54- and a 55-year-old, were analyzed by twodimensional electrophoresis without prior separation by size-exclusion and reversed-phase HPLC. ${ }^{13}$ In that study, several peptides from $\beta \mathrm{A} 4, \beta \mathrm{A} 3$ and $\gamma \mathrm{S}$ were recognized after in situ trypsin digestion and mass spectrometric analysis. Some masses suggested the presence of deamidation, but the signal-to-noise ratio was not adequate to locate the deamidations with certainty. In the present study, $\beta \mathrm{A} 4$ and $\beta A 3$ ( $\gamma \mathrm{S}$ had been removed by size-exclusion chromatogra- phy) were confirmed as components of spot 13 . Inclusion of the additional chromatographic steps improved the recovery of $\beta A 4$ and $\beta A 3$ so that peptides from all portions of the sequences were detected. The only peptides not detected were those with masses $<300 \mathrm{Da}$, the lower limit of the mass range being scanned. The signal-to-noise ratios of the mass spectra were adequate for determining the sites of deamidation as well as an estimate of the extent of modification from the isotopic patterns. With this procedure, the digest of spot 13 yielded peptides showing five sites of deamidation, three truncation sites and three oxidized methionines in $\beta \mathrm{A} 3$, as well as a deamidation, a truncation, an oxidized methionine and an oxidized tryptophan in $\beta A 4$. To determine whether these modifications may have occured during isolation, the lens from a 2-year-old was analyzed by the same procedure. No evidence for these modifications was found, indicating that they were in vivo modifications associated with aging.

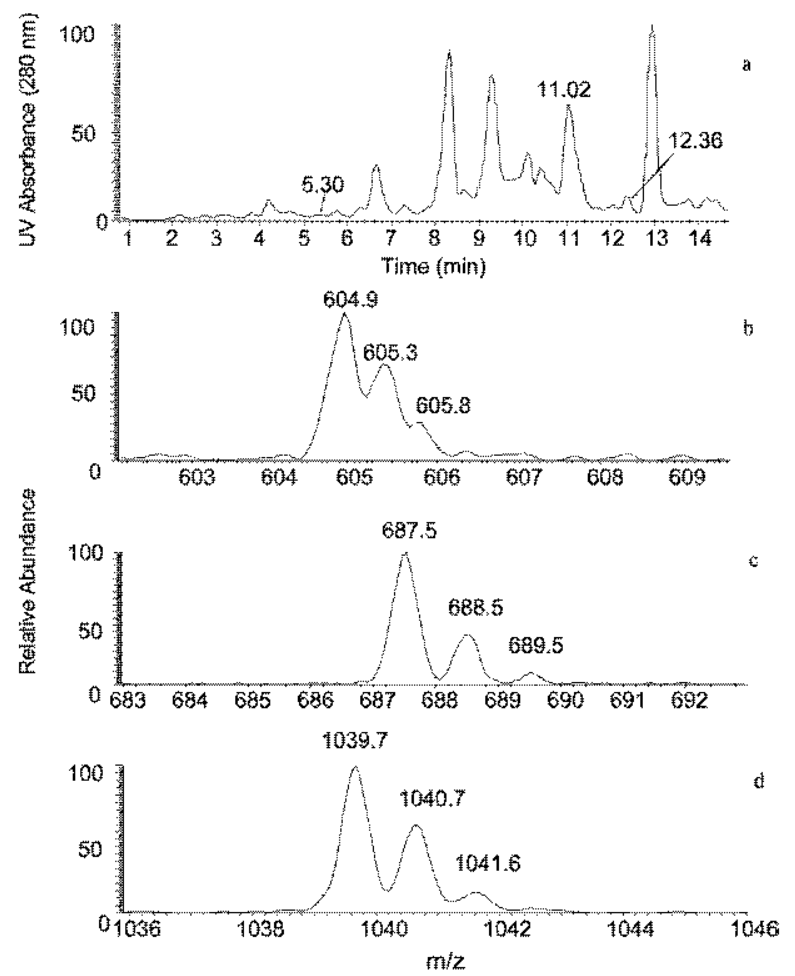

Figure 5. On-line LC-ESI-MS analysis of peptides from in-gel trypsin digestion of spot 13 (Figure 4). (a) Chromatogram of the reversed-phase HPLC separation of the peptides. (b) Mass spectrum of the peptide eluting at $5.30 \mathrm{~min}$. The peak at $\mathrm{m} / \mathrm{z}$ 604.9 is due to the doubly-charged ion of peptide 55-64, indicating cleavage of $\beta A 3$ between Asn 54 and Val 55 . (c) Mass spectrum of the peptide eluting at $11.02 \mathrm{~min}$. The peak at $\mathrm{m} / \mathrm{z}$ 687.5 is the singly-charged ion of peptide $27-32$ of $\beta A 3$, indicating cleavage of $\beta A 3$ between Gly 26 and Ser 27. (d) Mass spectrum of the peptide eluting at $12.36 \mathrm{~min}$. The peak at $\mathrm{m} / \mathrm{z}$ 1039.7 is the singly-charged ion of peptide $23-32$ of $\beta A 3$, indicating cleavage of $\beta A 3$ between Asn 22 and Pro 23 . 

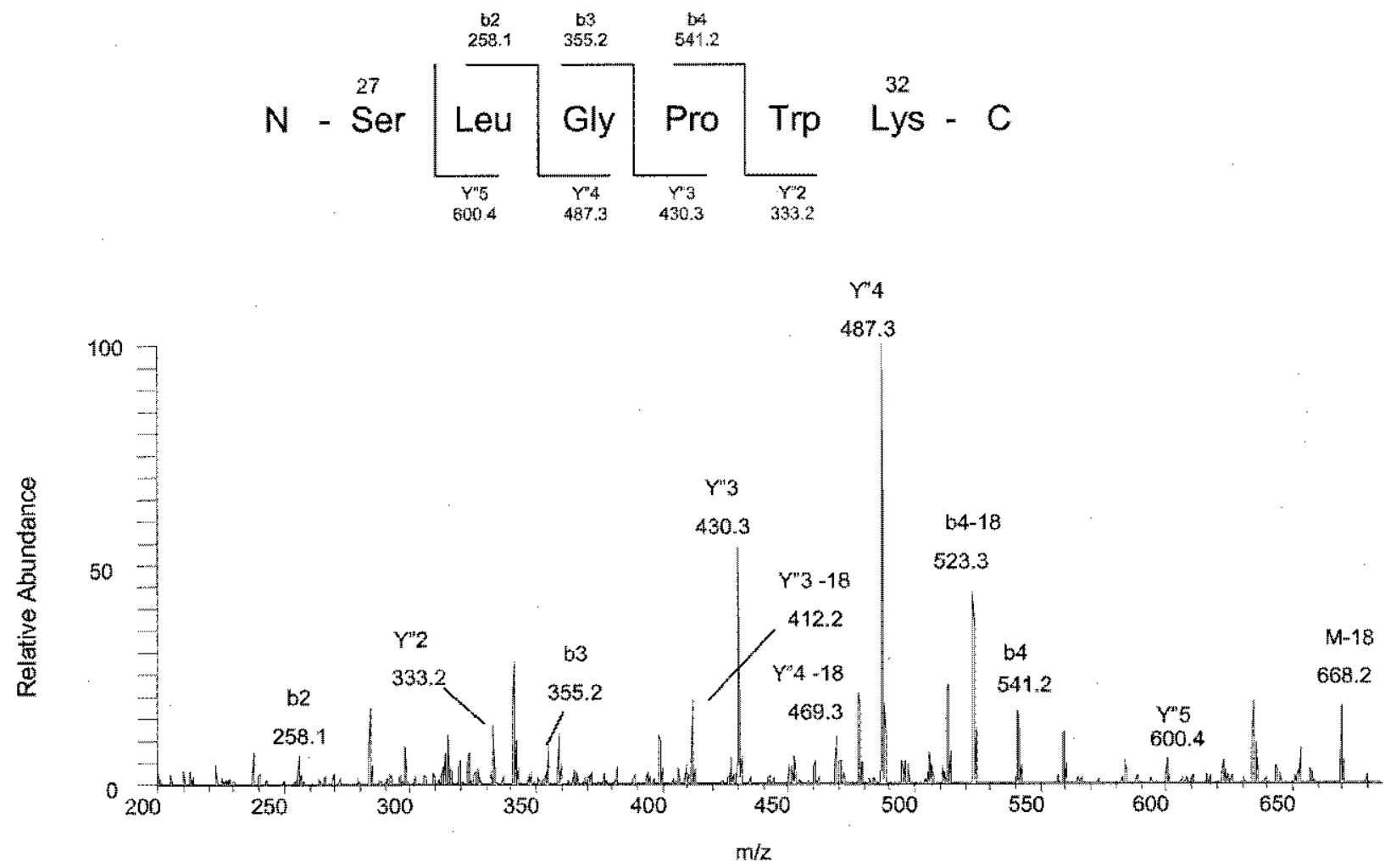

Figure 6. CID MS/MS spectrum corresponding to the mass spectrum in Figure 5(c). The sequence of $\beta$ A3 peptide 27-32 and the expected fragments are shown diagramatically at the top. Evidence of the corresponding fragments in the spectrum confirmed identification of this peptide as $\beta A 3$ 27-32. This peptide, which would not be produced by trypsin cleavage, indicates an in vivo cleavage site in $\beta A 3$ between Gly 26 and Ser 27.

Part of the on-line, reversed-phase HPLC chromatogram of tryptic peptides from spot 13 is shown in Figure 5(a). The mass spectra of three peptides (their elution times are marked) illustrating truncation of $\beta \mathrm{A} 3$ are shown in Figures 5(b), 5(c) and 5(d). The peak at $m / z 604.9$ in Figure 5(b) is the doubly-charged ion of peptide 55-64 of $\beta \mathrm{A} 3$, which elutes at $5.30 \mathrm{~min}$. It is a very minor component and, without pre-separation of $\beta$-crystallins by reversed-phase HPLC and separation of the $\beta B 1$ and $\beta A 4$ fraction by two-dimensional electrophoresis, it would not have been detected. The presence of this tryptic peptide indicates there has been cleavage between Asn 54 and Val 55. Because Asn 54 is one of the deamidated residues of $\beta A 3$, the presence of peptide 55-64 suggests that cleavage occurred after deamidation via the mechanism demonstrated for Asp 101 of $\alpha$ A-crystallins. ${ }^{21}$ The peak at $m / z 687.5$ in Figure 5(c) is the singly-charged ion of peptide $27-32$ of $\beta A 3$, which elutes at 11.02 min [Figure 5(a)]. Because Gly 26 / Ser 27 is not a tryptic cleavage site, the presence of this peptide indicates in vivo cleavage of $\beta A 3$. The peak at $m / z 1039.7$ in Figure 5(d) is the singlycharged ion of peptide $23-32$, eluting at $12.36 \mathrm{~min}$ and corresponding to the previously reported $\mathrm{N}$-terminal cleavage of $\beta A 3$ between Asn 22 and Pro 23. ${ }^{19}$ The in vivo cleavages in $\beta$ A3 at Gly 26 / Ser 27 and Asn 54 / Val 55 have not been previously reported.

The proteins in spot 13 were identified by LC-ESI-MS using both the dynamic-exclusion double-play mode and the general double-play mode. In the dynamic-exclusion double-play mode, the peptide with the highest intensity from the first full survey scan (centroid mode, 300 to $2000 \mathrm{~m} / \mathrm{z}$ ) is chosen as the parent ion. In the following CID MS/MS scan, this selected parent ion is fragmented into smaller daughter ions. This two-step cycle was repeated three times within $30 \mathrm{~s}$ (a typical peak width for peptides in a capillary HPLC separation) to obtain adequate signal for an $\mathrm{MS} / \mathrm{MS}$ spectrum of good quality. After that, the selected parent ion was excluded and the second parent ion was selected for MS/MS analysis, even though the previously chosen ion was still the strongest ion in the scan at that time. Compared with a general double-play operational mode, more peptide ions can be selected during one run and thus more sequence information can be obtained. The general double-play (profile) mode demonstrates the isotopic envelope of peptides, which can help confirm the identities of peptides by their charge states. This operational mode is quite useful in characterizing some modifications of peptides, such as deamidation. The combi- 


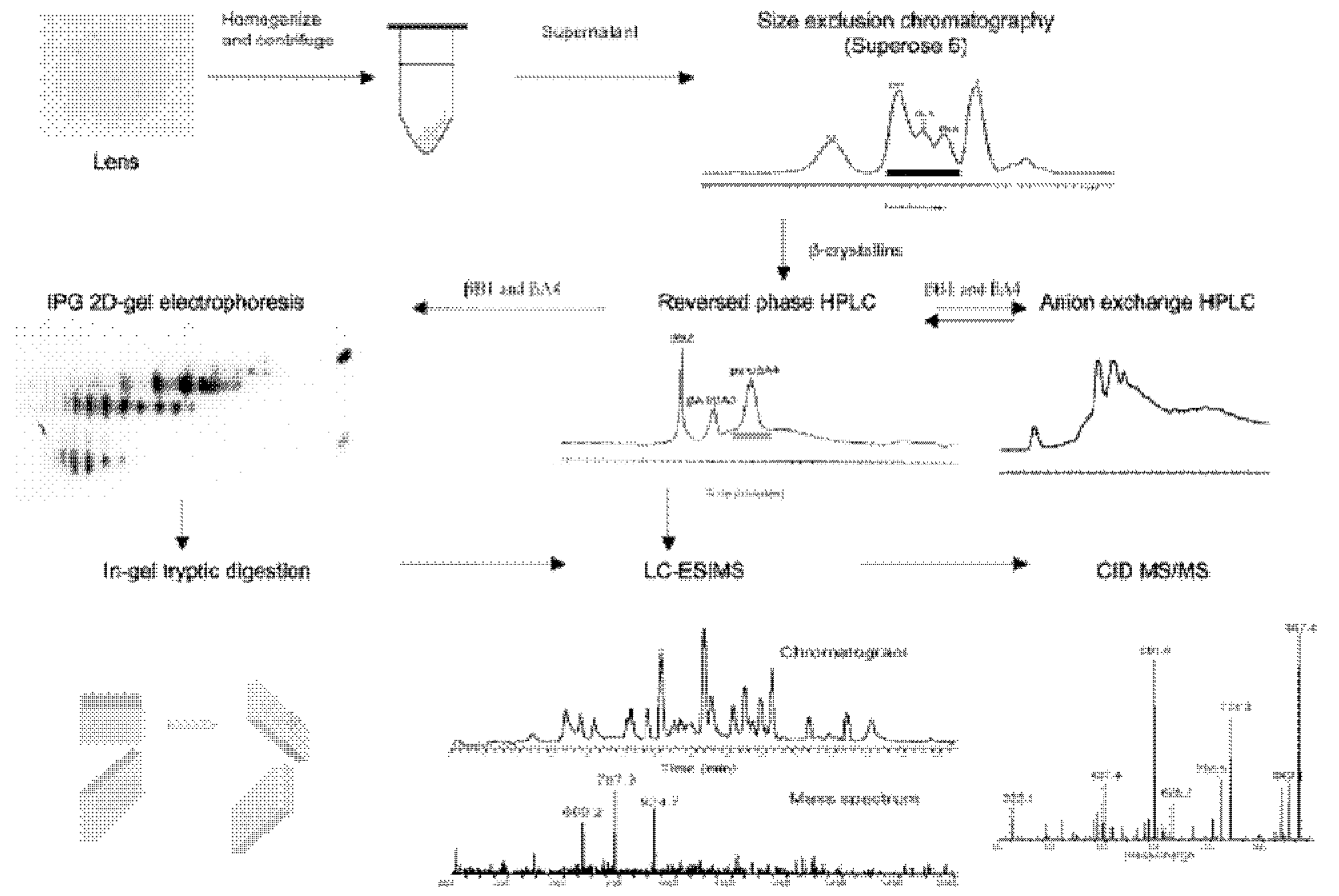

Figure 7. Diagram of the multiple steps used to identify human lens $\beta$-crystallins and their modifications. The examples are from the $\beta \mathrm{B} 1$ and $\beta \mathrm{A} 4$ peak of the reversed-phase fractionation.

nation of these two modes provides more comprehensive information about the peptides. An example of CID MS/MS confirmation of a modification is shown in Figure 6. The spectrum shows the fragment ions produced by $\beta A 3$ peptide 27-32 [Figure 5(c)] which eluted at $11.02 \mathrm{~min}$. The ions of the $\mathbf{b}$ - and $\mathbf{y}$-series confirm that the peptide has the sequence given at the top and that there is in vivo cleavage of $\beta \mathrm{A} 3$ between Gly 26 and Ser 27.

\section{Concluding remarks}

A summary of the procedure used in this examination of $\beta$-crystallins is given in Figure 7 . For these proteins, prior size-exclusion chromatography and reversed-phase HPLC reduced the number of components per spot in the twodimensional electrophoresis gels and improved the signalto-noise ratio in the subsequent mass spectrometric analyses. The recovery of peptides from in-gel digestion was as effective as would be obtained from test tube digestion. Although anion-exchange chromatography was not useful for $\beta$ crystallins, inclusion of an ion-exchange step may be effective for other protein mixtures. Improved ESI mass spectra were obtained by including traps to remove chemicals used in the gel separations as well as by reversed-phase HPLC immediately before mass spectral analysis. This type of procedure, with appropriate variations, will find application in identifying the modifications of proteins from many complex biological samples.

\section{Acknowledgements}

This investigation was supported by the National Institutes of Health Research Grant RO1 EY07609 and the Nebraska Center for Mass Spectrometry. This manuscript was prepared while DLS and JBS were on sabbatical leave at the Institut de Biologie Structurale, Grenoble, France.

\section{References}

1. A. Shevchenko, O.N. Jensen, A.V. Podtelejnikov, F. Sagliocco, M. Wilm, O. Vorm, P. Mortensen, $\mathrm{H}$. Boucherie and M. Mann, Proc. Natl. Acad. Sci. USA 93, 14440 (1996).

2. M. Mann and M. Wilm, Anal. Chem. 66, 4390 (1994). 
3. J. Eng, A.L. McCormack and J.R. Yates, J. Am. Soc. Mass Spectrom. 5, 976 (1994).

4. A.L. McCormack, D.M. Schieltz, B. Goode, S. Yang, G. Barnes, D. Drubin and J.R. Yates, III, Anal. Chem. 69, 767 (1997).

5. L.A. Holland and J.W. Jorgenson, Anal. Chem. 67, 3275 (1995).

6. R.J. Anderegg, D.S. Wagner, R.K. Blackburn, G.J. Opiteck and J.W. Jorgenson, J. Protein Chem. 16, 523 (1997).

7. G.J. Opiteck and J.W. Jorgenson, Anal. Chem. 69, 2283 (1997).

8. J.P. Larmann, Jr, A.V. Lemmo, A.W. Moore, Jr and J.W. Jorgenson, Electrophoresis 14, 439 (1993).

9. A.W. Moore, Jr and J.W. Jorgenson, Anal. Chem. 67, 3464 (1995).

10. E.R. Berman, Biochemistry of the Eye. Plenum Press, New York, pp. 236-240 (1991).

11. Z. Ma, S.R. Hanson, K. Lampi, L. David, D.L. Smith and J.B. Smith, Exp. Eye Res. 67, 21 (1998).

12. A.L. Lund, J.B. Smith and D.L. Smith, Exp. Eye Res. 63, 661 (1996).

13. K.J. Lampi, Z. Ma, S.R.A. Hanson, M. Azuma, M. Shih, T.R. Shearer, D.L. Smith, J.B. Smith and L.L. David, Exp. Eye Res. 67, 31 (1998).

14. T.S. Meyer and B.L. Lamberts, Biochim. Biophys. Acta 107, 144 (1965).
15. N.M. Matsui, D.M. Smith-Beckerman and L.B. Epstein, in Methods in Molecular Biology: Proteome Analysis Protocols, Vol 112, Ed by A.L. Link. Humana Press, Totowa, NJ, USA, pp. 307-311 (1999).

16. P.L. Courchesna and S.D. Patterson, in Methods in Molecular Biology, Vol. 112, Ed by A.L. Link. Humana Press, Totowa, NJ, USA, pp. 487-511 (1999).

17. Z. Yang, M. Chamorro, D.L. Smith and J.B. Smith, Curr. Eye Res. 13, 415 (1994).

18. C. Slingsby and O.A. Bateman, Exp. Eye Res. 51, 21 (1990).

19. K.J. Lampi, Z. Ma, M. Shih, T.R. Shearer, J.B. Smith, D.L. Smith and L.L. David, J. Biol. Chem. 272, 2268 (1997).

20. L.L. David, K.J. Lampi, A.L. Lund and J.B. Smith, J. Biol. Chem. 271, 4273 (1996).

21. C.E.M. Voorter, W.A. de Haard-Hoekman, P.J.M. van den Oetelaar, H. Bloemendal and W.W. de Jong, J. Biol. Chem. 263, 19020 (1988).

Received: 6 February 2001 Revised: 23 April 2001 Accepted: 1 May 2001

Web Publication: 12 July 2001 